Article

\title{
Social and Ecological High Influential Factors in Community Gardens Innovation: An Empirical Survey in Italy
}

\author{
Vincenzo Rusciano, Gennaro Civero and Debora Scarpato * \\ Department of Economic and Legal Studies, University of Naples Parthenope, 80133 Naples, Italy; \\ vincenzo.rusciano@uniparthenope.it (V.R.); gennaro.civero@uniparthenope.it (G.C.) \\ * Correspondence: debora.scarpato@uniparthenope.it; Tel.: +39-346-806-3937
}

Received: 30 April 2020; Accepted: 3 June 2020; Published: 6 June 2020

check for updates

\begin{abstract}
In 2015, The United Nations adopted an agenda for sustainable development in order to obtain "a shared blueprint for peace and prosperity for people and for the world now and in the future (United Nations). The United Nations has defined 17 main goals, such as ending poverty, improving health, preserving the ocean, and tackling the climate change, in order to achieve worldwide sustainable development. Sustainable development is a crucial worldwide topic that encompasses three dimensions: economic, social and environmental. Nowadays, social ecological innovation has envisaged a new prominent business model focusing on social and environmental goals to achieve sustainable development. The intent of this paper is to propose the community garden framework as a social and ecological innovation tool in order to boost sustainable development in urban areas as well as rural areas. For this purpose, an empirical analysis based on a structured interview was conducted in the area of Naples on a sample of 150 gardeners. The results of the interviews have been aggregated by using a variance and correlation analysis in order to explore to what extent the social and environmental dimensions are linked to the community gardens and to identify a pattern between community gardens and social ecological innovation. Two attributes of community gardens, that is, urbanization effects mitigation and wellness and community, were identified as having the ability to influence other community garden attributes. Thus, the paper suggests using these highly influential factors to define a social and ecological innovation strategy based on a community gardens framework.
\end{abstract}

Keywords: community garden; sustainable development; social ecological innovation; sustainable city; social farming

\section{Introduction}

Historically, "Sustainable Development" was associated with a negative meaning rather than a positive one [1]. It was often seen as a prohibition and limitation, and for which strict laws were applied, for example by limiting the production of greenhouse gases. Specifically, the concept of a "sustainable city" refers much more to restrictions and bans than to "positive" life practices promoted by public authorities [2].

Many scholars are debating on new sustainable strategies and the concept of social innovation is envisaged as a new business model in order to achieve social goals [3]. Nowadays, social innovation is gaining a lot of interest in the academic literature in addressing social issues. However, social innovation is mainly focused on the social dimension without properly addressing the impact on the ecological side. Thus, social innovation should evolve as a broader social ecological innovation in order to guide society towards social, ecological and sustainable transformations and outcomes. 
Among the various models of social ecological, innovation, community gardens could represent a different and viable way to enhance the value of the environmental dimension as well as the social one. The current academic literature provides numerous testimonies of the social, environmental and economic dimensions of community gardens. However, there are no empirical studies that analyze community gardens from the perspective of socio ecological innovation. Therefore, the intent of this article is to provide empirical evidence of the multidimensionality of community gardens in order to determine a social and ecological innovation strategy for sustainable development based on the community gardens framework. Thus, enhancing community garden attributes can trigger a virtuous social innovation mechanism aimed at the sustainable transformation of urban areas and, moreover, also applicable to rural areas.

The hypotheses of this study are:

Hypothesis 1 (H1). Community gardens are mainly influenced by social and environmental dimensions. Thus, they can be considered as social ecological innovation tools.

Hypothesis 2 (H2). Social and environmental attributes correlate each other. So, Policy makers need only implement few attributes in order to maximize the effect of community gardens based on social ecological innovation.

The empirical analysis is based on the direct survey of 150 gardeners in the area of Naples. Subsequently, the data gathered were analyzed by using a variance and correlation analysis.

The structure of the article is organized as follows. After this introduction, the second chapter profiles the urban garden and the social innovation theory according to the most recent studies. The third one describes the method adopted within the present study. The fourth chapter provides the result of the analysis by showing the most important attributes of community gardens. The fifth chapter provides the interpretation of the result integrated by additional academic studies in order to validate the hypotheses. Finally, the conclusions offer some suggestions for using the result of the article as well as suggestions for further studies.

\section{Theoretical Background}

According to Keeble [4], sustainable development is "Development that meets the needs of the present without compromising the ability of future generations to meet their own needs". Thus, this definition aims to achieve global economic welfare by preserving the Earth's resources and the environment. This means environmental, economic, social and institutional improvement, both locally and globally, to achieve immediate objectives without jeopardizing future ones. This concept always encompasses these three dimensions: economic, social and environmental.

According to Duit and Galaz and Walker et al. [5,6], new management and governance systems are acutely needed to find more sustainable pathways in order to deal with the current society challenges. Social Innovation is recognized as an innovative solution to sustainability challenges. Phills, Deiglmeier and Miller [7] define social innovation as: "A novel solution to a social problem that is more effective, efficient and sustainable than existing solutions and for which the value created accrues primarily to society as a whole rather than to private individuals".

Cunha, Benneworth and Oliveira [8] summarize the key aspects of social innovation by highlighting the following two distinct groups of characteristics that underlie its definitions:

- Long-term social value creation: Social Innovation is concerned with social justice for the society as a whole. It focuses on social value creation and community development through collaborative action to deliver benefits over a long term.

- Novel system-changing solutions: Social Innovation leverages, cross-sectoral and cross-disciplinary insights, to deliver novel solutions that are system-changing. 
Thus, Social Innovation is able to achieve benefit for society and also enhance society's capacity to act [9]. Topics dealt with in the literature on sustainability and social innovation are focused more deeply on the conditions and dynamics of innovations and their role for a wider transformation of models in social organization and collective decision-making [10-12]. Hence, the main goal of social innovation is to achieve sustainable transformation to for meet social needs. According to Nicholls and Murdock [13], major transformations in societies can occur without improving their capacity to learn from, respond to and manage environmental feedback from dynamic ecosystems. From this perspective, social innovation can be an important mean for changing societies, but the reduced or non-existent ability to incorporate the ecological dimension can lead to non-sustainable transformation and development. Sustainable innovation must consider the environmental dimension as a driver as well as the social and economic ones. For example, nowadays there is gradual shift to bio fuels as a way to mitigate climate change [14,15], but this solution could have the drawback of leading to destructive land-use change and biodiversity loss [16]. Thus, the environmental dimension must be explored in depth in order to evaluate the real impact on the ecosystem, otherwise any societal transition could lead to further ecological degradation that would be difficult to get out of [17]. Therefore, the Social Innovation should evolve as a broader social ecological innovation in order to guide society towards social ecological sustainable transformation and outcomes. According to Olsson and Galaz [3], social ecological innovation is "social innovation, including new technology, strategies, concepts, ideas, institutions, and organizations that enhance the capacity of ecosystems to generate services and help steer away from multiple earth-system thresholds".

Social and ecological innovation could be beneficial to overcome the challenges related to the production of food. The world population grows more and more, and we must face the imposing demand for food both in terms of quantity and variety. According to Gordon et al. [18], food production has a significant impact on climate change, biodiversity and land system change. Moreover, dietary habits and consumption patterns based on high animal-based products and low vegetable products put further pressure on the planet, as the first are generally less calorie-efficient and emit more greenhouse gases [19]. Besides these environmental challenges, agri-food systems also face social challenges such as inequality and marginalization [20]. Consequently, a transformation of the agri-food systems towards sustainability is necessary in order to ensure planetary health, which is fundamental for human wellbeing $[17,21]$.

In the urban context, this problem leads to a shift in attention towards city gardening, where urban agriculture now dominates the discussion [22]. According to Simon-Rojo [23], urban agriculture is divided into two major macro categories: urban farming and community gardening. The first is associated with farms located in the urban area. The second is associated with everything concerning the small-scale urban cultivation of both edible and aromatic plants and plants for ornamental purposes.

According to Urban Agriculture Committee of the CFSC, the community gardens are cultivation activities, public or private, occurring within the urban areas for the production of vegetables, flowers and fruit.

The community gardening can be further deployed in:

- Gardens for individual production purposes (e.g., family gardens).

- Gardens with collective management and production (e.g., therapeutic, or shared gardens).

From this perspective, community gardening can offer affordable and convenient access to fresh products, particularly for urban populations with limited access to supermarkets. In the last decade, there was an explosion of interest of gardening. The role and potential of gardening within the city is presently seen as integral to making local and healthy foods more accessible, mitigating the negative impacts of urbanization, lowering carbon emissions, and encouraging emerging forms in the community and sociality in the urban space; all of these benefits resonate with sustainability goals [24].

Community gardens can also guarantee the protection of biodiversity and promote a model of agriculture that excludes chemical products for crops, avoiding pesticides as much as possible and 
ensuring the use of sustainable best practices such as containers for waste separation [25]. Some studies have investigated the environmental benefits of community gardening. The expansion of green areas in the city, including community gardens, improves the microclimate through the evapotranspiration process [26]. The green areas help in removing energy and heat from the atmosphere and producing water vapor. This process is useful during the summer or in dry areas, since a greater humidity in the air and less energy in the atmosphere contribute to the achievement of comfort in poorly ventilated urban areas [27]. The presence of trees but also herbaceous plants reduces suspended dust and the polluting charge of many compounds, including nitrogen dioxide [28]. Thus, the environmental impact of community gardens is clear. In addition, the Technical University of Crete has also empirically proved the benefits of community gardens in reducing the temperature of the air and the earth's surface temperature in an experiment conducted in the Chalepa district in Greece [29].

Most studies have also researched the benefits of community gardening for community development [30]. According to Sanecka et al. [31], community gardens are examples of stewardship arenas where people can re-connect with nature by building social cohesion and promoting democratic values through cooperation and debate. With community gardens, the gathering and passing on of practices, knowledge and experience for community building and management of local ecosystems through the preservation of social-ecological memory is possible [32]. According to Filkobski [33], community gardens support community cohesion, as they have the ability to create a civil conscience towards green areas. This research also states that community gardens are capable of embellishing neighborhoods for the benefit of residents, who then feel more pride and attachment to the area in which they live [34]. Nowadays, community gardens are designed to be a resource for the development of a parallel economy, based on a network of relationships, sharing of values and objectives to support the community. Community gardens have triggered a collaboration mechanism (sharing economy) among various urban farmers that generate positive effects in terms of economy, health and knowledge [35].

According to Grahn, Demers and Kingsley [36], it is clear that community gardens create relationships between individuals and territories and are considered therapeutic, especially for older people with mental disorders because they are an excellent anti-stress activity. The practice of garden therapy renders the garden a habitat for enhanced wellbeing and healing for fragile people or people going through particularly difficult phases of their lives [37-39]. The possibility of having a visible result offers a sense of accomplishment of a craft, which is not only work for its own sake but a way to practice what has been learned about gardening [40]. Each garden answers the challenge to create a more sustainable lifestyle because it represents the ideal habitat for promoting processes of change towards a more sustainable community, [41] encouraging the abandonment of behaviors harmful to people like excessive urbanization and promoting the quality of the environment and human society [33,34,42]. The care of a vegetable garden involves taking responsibility not only for oneself and one's surroundings but also for future generations [43]. The spread of community gardens has had a positive and direct impact on people's health by reducing the risk of disease that a sedentary and isolated life can lead to, resulting in decreased costs in public health [44]. Through community gardens, concrete, everyday practices become a steppingstone to a horizon of values and ideals for the future of the planet. Community gardens are an effective way for people to learn how to value food, nature and the environment [45].

According to Sepúlveda and Edwards, Camps-Calvet et al. [46,47], community gardens provide opportunity for empowering local communities, improving their quality of life by creating new jobs, promoting certain food products, generating new revenue streams, forms of solidarity, aggregation and integration among the various actors and educating younger generations to respect the environmental characteristics of an area.

Community gardens are the first and most concrete connection between urban reality and rural culture because they support the transformation of the cities and allow urban gardeners to maintain relationships with rural culture [47-49]. 
Therefore, whatever the typology of community gardens, they always embody the three dimensions of sustainability: social, environmental, and economic. Thus, they can act as a powerful social innovation agent. In fact, according to the University of Manchester, the term urban social-ecological innovation (USEI) includes a "wide array of urban ecological movements which have been described through a broad and often complex social-ecological nomenclature including: Civic ecology [50], urban environmental movements [51], social-ecological innovation [3] and organized social-ecological innovation [52], community-based urban land management [53], urban greening [54], user participation [55], collectively managed community gardens [55], community gardening [56] and community agriculture [51]". Thus, community gardens are clearly a social-ecological innovation tool to achieve sustainable development.

\section{Methodology}

An empirical analysis based on a structured interview (questionnaire) prepared by Parthenope University and distributed to a sample of 150 gardeners in the area of Naples was conducted by using a purposive sampling. The following process was applied to define the sample and questionnaire and to achieve the maximum level of data integrity and homogeneity.

- $\quad$ STEP 1 identification of the number of representative community gardens by sampling

A. Selection of the Area.

The choice of the Naples area was mainly due to the already deep knowledge of the context and the actors, with a better managing communication with the population and a better understanding of the network of relationships.

B. Selection of the driver aspects on community gardens.

The aim of this analysis was the identification of macro-categories of community gardens community. The following categories were identified:

- Management: private or public;

- Size: big or small;

- Location: urban and peri-urban area.

C. Selection of the number of community gardens to use for the statistical analysis with the aim of maximizing the cost-benefit effects.

Two community gardens were selected to cover all macro-categories.

- $\quad$ STEP 2 identification of the number of people to be interviewed

D. Identification of stakeholders to interview and the definition of quotas by gender, age, educational level.

The choice of stakeholder was mainly influenced by the need to trace a large and significant part of the population. In addition, no reliable data were already available on stakeholder's distribution for gender, age or educational level. This factor led us to submit a questionnaire on almost all the stakeholders available in the selected community gardeners. The following stakeholders were identified and interviewed: head of organizations, direct-producers, farmers, parents and relatives of the farmer, municipal organizations and all the people involved in urban garden activities in general. In the frame of our analysis these stakeholders were identified as gardeners.

E. Determination of the sample size.

The number of 150 was considered adequate based on the author's judgment, because no official data were available. 


\section{- $\quad$ STEP 3 Questionnaire preparation and validation}

F. Determination of questions.

The questions were defined on the basis of an analysis of the academic literature and on similar empirical experiences.

G. Questionnaire validation.

The questionnaire was reviewed by small number of stakeholders, with the function of checking the quality of the questions.

H. Questionnaire submission.

The stakeholders were invited to fill questionnaire voluntarily and anonymously.

According to this criteria, two gardens were selected for this study. The first one, within the urban area of Naples, is the Social Garden of Health and Wellness of Ponticelli situated inside the De Filippo City Park. This garden consists of one hectare of land dedicated to community gardens. It is managed by the municipality through several organizations. The second one was in Soccavo, in the peri-urban area of Naples, where the Progetto Pace Association uses around 1000 square meters for community garden purposes. These two typologies of gardens were selected because they were representative of public and private community garden management, urban and peri-urban community gardens, as well as small and big community gardens. Therefore, we decided to interview the following set of stakeholders involved in the urban garden activity in the Naples area: head of organizations, direct-producers, farmers, parents and relatives of the farmer, municipal organizations and all the people involved in urban garden activities in general [48]. The timeframe of this survey was limited to a data collection session in the months of October and November 2016. The questionnaire was filled in anonymously by the sample. Moreover, the questionnaire included a disclaimer to be authorized on using the information for academic research studies. The questionnaire was divided into five sections. The first relates to the degree of satisfaction and the methods of use with the practice of community gardens; the second part is aimed at detecting the social function performed by the community garden; the third concerns the environmental function of the vegetable garden; the fourth investigates the economic function, and finally the last section includes questions related to the personal data of the interviewees. The questionnaire was created in order to associate a metric scale from 1 to 5 for each variable according to Likert Scale. The value 1 corresponds to the absence of relevance given to the variable, while the value 5 indicates the high relevance given to the variable. Table 1 depicts the scale.

Table 1. Likert scale used for the Questionnaire.

\begin{tabular}{cccccc}
\hline Attribute & $\mathbf{1}$ & $\mathbf{2}$ & $\mathbf{3}$ & $\mathbf{4}$ & $\mathbf{5}$ \\
\hline Frequency & Never & Rarely & Occasionally & Frequently & Always \\
Agreement & Strongly Disagree & Disagree & Undecided & Agree & Strongly Agree \\
Importance & Not Important & Slightly Important & Moderately Important & Important & Very Important \\
\hline
\end{tabular}

Only the agreement attribute was applicable to the social, environmental and economic variables analyzed in this study. We applied this approach in order to perform a quantitative analysis of the data collected. The investigation was focused on social and environmental variables to highlight the social-ecological dimensions of community gardens. In addition, the economical dimension was also analyzed in order to compare the weight of these three functions. Therefore, the analysis was performed by using the following three groups of variables: Social, Environmental and Economic (Table 2). A preliminary literature review on community gardens was performed in order to properly select the variables appropriately.

The references [30,32,57-61] were used as bibliographic sources to identify the variables.

A preliminary analysis was performed to select the significant community garden factors according to criteria based on high mean (average) and small variance (p. 7). The significant community garden factors were selected on the basis of the following criteria: 
- $\quad$ Average, more than 4;

- Variance, less than or equal to one.

Table 2. Social, Environmental and Economic variables of Questionnaire.

\begin{tabular}{|c|c|c|}
\hline Social & Environmental & Economic \\
\hline $\begin{array}{l}\text { Socialization and environmental education } \\
\text { for children; }\end{array}$ & Redevelopment of empty or abandoned areas; & Saving food costs; \\
\hline $\begin{array}{l}\text { Socialization and historical memory for } \\
\text { retired people; }\end{array}$ & Urbanization effects mitigation; & Job opportunities; \\
\hline Support in integration activities for disabled people; & Recovery of vegetable plants; & $\begin{array}{l}\text { Creation of a collective and } \\
\text { shared consumption; }\end{array}$ \\
\hline $\begin{array}{l}\text { Support in reintegration activities for } \\
\text { the unemployed; }\end{array}$ & Enhancement of local products; & \\
\hline $\begin{array}{l}\text { Strengthening and sense of community; } \\
\text { Wellness and community; }\end{array}$ & $\begin{array}{l}\text { Increased knowledge of cultivation techniques; } \\
\text { Use of natural fertilizers; }\end{array}$ & \\
\hline
\end{tabular}

According to these criteria, the subsequent analyses were performed only to those variables that are considered as very relevant for most of the sample (e.g., the eight variables in bold, as per Table 3). The significant community garden factors were analyzed by using the Analysis of Variance (ANOVA one-factor) and the correlation analysis using Microsoft Excel. It is a parametric statistical technique used to compare datasets and to detect differences in means (averages) between various levels of a factor, or between different groups [62]. According to von Eye and Bogat [63], this method can be applied both in the context of variable-oriented research and in person-oriented research. In this perspective, this analysis was performed to get insight information on the significant community garden factors as well as on the relevant group orientations. Although ANOVA is widely used, it was important to check the validity of key assumptions before applying the analysis to the questionnaire data. As discussed by Hogg and Ledolter [64]. These assumptions are:

- The values for each level follow a Normal (a.k.a., Gaussian) distribution.

- The variances are the same for each level (Homogeneity of Variance).

Table 3. The mean and the variance of social, environmental, and economic variables.

\begin{tabular}{ccc}
\hline Variable & Mean & Variance \\
\hline Socialization and environmental education for children & 3.78 & 1.06 \\
Socialization and historical memory for retired people & 4.09 & 1.05 \\
Support in integration activities for the disabled people & 3.57 & 1.13 \\
Support in reintegration activities for the unemployed & 3.46 & 1.11 \\
Strengthening and sense of community & 4.31 & 0.58 \\
Wellness and community & 4.22 & 0.87 \\
Cost savings for social services & 3.19 & 1.24 \\
Redevelopment of empty or abandoned areas & 4.52 & 0.68 \\
Urbanization effects mitigation & 4.39 & 0.90 \\
Recovery of vegetable plants & 3.87 & 1.27 \\
Enhancement of local products & 4.20 & 0.97 \\
Increased knowledge of cultivation techniques & 4.16 & 0.82 \\
Use of natural fertilizers & 4.42 & 0.96 \\
Saving food costs & 3.55 & 1.32 \\
Job opportunities & 3.07 & 1.48 \\
Creation of a collective and shared consumption & 3.82 & 1.33 \\
\hline
\end{tabular}

The 8 variables in bold fulfill the criteria as per Section 3 .

Hence, the ANOVA was performed to evaluate the differences in means between different community garden factors and for different age classes of the selected sample. The aim of the latter evaluation was to identify to what extent the significant community garden factors are influenced by different age classes within the sample of 150 gardeners. To this purpose, the sample was decomposed into age classes to verify whether age influences the weight of the selected significant variables. The following two age classes were selected 
- 35-50;

- $50-65$

as they represented about $80 \%$ of the total (118 out of 150 ). The analysis was also performed for the age classes $25-50$ and over 50 , equivalent to $96 \%$ of the sample, with no significant variations in the results. Thus, ANOVA was used to verify that the significant community garden factors are not influenced by the age (i.e., this is null hypothesis, H0). For this purpose, a statistical test, called the $\mathrm{F}$ test, was applied. The F test is simply a ratio between two variances and follows the value of the $\mathrm{F}$ distribution. It was used to verify the null hypothesis. Basically, the value of the test $\mathrm{F}$ is compared with the statistical critical value F, depending on the significance level chosen (e.g., the selected significant level was $p$-value $=0.05(5 \%)$. ANOVA uses the $\mathrm{F}$ test to determine whether the variability of the means between the groups (e.g., between $35-50$ and 50-65) is greater than the variability of the observations within the groups (e.g., within 35-50 and within 50-65). The result of this analysis provides important information to state whether or not the significant community garden factors are universally accepted by the whole sample without any difference due to age. This information is critical for any stakeholder with the intention of introducing social innovation strategies based on a Community Garden. Basically, if the ratio is sufficiently large, it is possible to conclude that not all averages are equal, and therefore the null hypothesis is rejected. On the contrary, if the value is low enough, the null hypothesis is confirmed.

In the frame of this paper:

- The null hypothesis is verified, $\mathrm{F}<$ Fcrit;

- The null hypothesis is rejected, $\mathrm{F}>$ Fcrit.

The results of the questionnaire were further analyzed by using the Pearson correlation analysis. This is a statistical method used to evaluate the strength of the relationship between community gardens variables [65] and to obtain information on the predictive relationship between the significant community garden factors that can be exploited in practice. In other words, the correlation coefficients were used to evaluate the strength (direction and magnitude) of the relationship between two variables [66]. However, correlation does not imply causation [67]. Thus, using only the correlation analysis, it is not possible to state a cause-and-effect relationship. Hence, an additional test was needed to test the significance of Pearson's correlation coefficient or, in other words, the linear relationship between independent community garden factors. According to Student [68] and Fisher [69], the significance of correlation coefficients can be tested by using Student $t$-distribution and the Fisher z-transformation [67]. For the purpose of this paper, the Student's $t$-test (e.g., $t$-test in Microsoft Excel) was applied to evaluate the significance of the correlation coefficients. This test makes it possible to calculate the significance according to probability $(\mathrm{p}$ ) levels and gives information on the likelihood that the correlation coefficient will occur with no relationship within the selected sample. It must be noted that a smaller $p$ level indicates a more significant relationship [67]. In the frame of this study, a value of $p$ less than or equal to $0.05(5 \%)$ was considered acceptable in order to state that significant community gardens factors are directly related to each other. Hence, the most correlated factors were identified as high influential factors because on changing them; there is an important effect on the others as well, and the total result is maximized.

\section{Results}

The first step was the calculation of the mean (average) and the variance in social, environmental and economic variables in order to define the most significant ones as depicted in the Table 3.

The first evidence of these results is the low score of economical motivation compared to the social and environmental ones; in fact, few interviewees declared that they practiced gardening for economical purposes. All three variables of this category do not have a strong impact on the interviewees. On the other hand, the questions related to the social and environmental function of 
community garden cultivation are the most significant in terms of average score and variance. This first result was important in order to focus the analysis only on the social and environmental variables. According to the results, eight variables were identified as truly relevant for most of the sample (e.g., the eight variables in bold as per Table 3). The socialization and historical memory for retired people was considered as compliant to the criteria even if the variance exceeds the selected limit (e.g., $1.05 \approx 1$ ). These variables were identified as significant factors for community gardens. Thus, these variables were analyzed by using ANOVA to check whether or not the average of eight social and environmental variables are influenced by age.

The Table 4 below shows the result of the analysis.

Table 4. ANOVA analysis results ${ }^{1}$.

\begin{tabular}{|c|c|c|c|c|c|c|c|}
\hline Variable & Source of Variation & $\begin{array}{l}35-50 \\
\text { Mean }\end{array}$ & $\begin{array}{c}35-50 \\
\text { Variance }\end{array}$ & $\begin{array}{l}50-65 \\
\text { Mean }\end{array}$ & $\begin{array}{c}50-65 \\
\text { Variance }\end{array}$ & $\mathbf{F}$ & F crit \\
\hline $\begin{array}{l}\text { Socialization and historical memory } \\
\text { for retired people }\end{array}$ & Between Groups & 4.07 & 1.08 & 4.07 & 1.03 & 0.0082 & 3.9243 \\
\hline Strengthening and sense of community & Between Groups & 4.33 & 0.43 & 4.47 & 0.36 & 1.3913 & 3.9243 \\
\hline Wellness and community & Between Groups & 4.40 & 0.42 & 4.17 & 0.81 & 2.3674 & 3.9243 \\
\hline $\begin{array}{l}\text { Redevelopment of empty or } \\
\text { abandoned areas }\end{array}$ & Between Groups & 4.60 & 0.63 & 4.43 & 0.88 & 1.1414 & 3.9243 \\
\hline Urbanization effects mitigation & Between Groups & 4.48 & 0.64 & 4.31 & 1.13 & 0.9740 & 3.9243 \\
\hline Enhancement of local products & Between Groups & 4.34 & 0.62 & 4.22 & 1.12 & 0.4855 & 3.9243 \\
\hline $\begin{array}{l}\text { Increased knowledge of } \\
\text { cultivation techniques }\end{array}$ & Between Groups & 4.24 & 0.75 & 4.33 & 0.57 & 0.3259 & 3.9243 \\
\hline Use of natural fertilizers & Between Groups & 4.43 & 0.85 & 4.5 & 0.82 & 0.1660 & 3.9243 \\
\hline
\end{tabular}

${ }^{1}$ This table provides the comparison between Group Age 35-50 and 50-65.

As shown in the tables, the $\mathrm{H} 0$ is accepted for all variables (e.g., $\mathrm{F}>$ Fcrit and $p$-Value $>0.05$ ), so the age classes do not influence the social and environmental variables. The significant social and environmental factors are equally important in the different age classes of the sample. Thus, this result provides evidence of the robustness of the selected social and environmental variables.

In addition to ANOVA, a correlation analysis was carried out to understand the mutual dependence between the variables (Table 5). The analysis shows how the variables are related to each other and how the change in one variable could influence another. This result was fundamental in evaluating the most powerful variables (called High Influential Factors) in terms of ability to influence other variables. This result represents a crucial information for any stakeholder, e.g., Institution and Policy Makers, to optimize social and ecological innovation strategies based on community gardens.

Table 5. Correlation analysis results ${ }^{1}$.

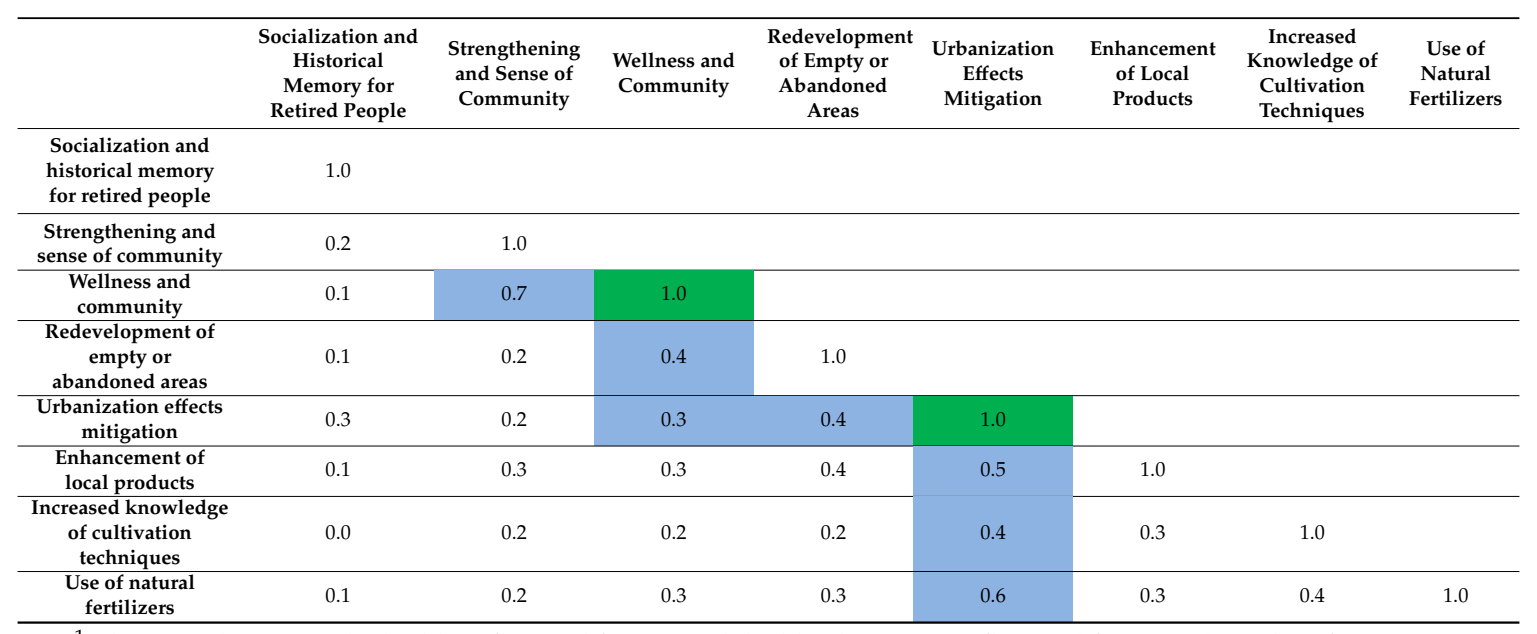

${ }^{1}$ The green boxes are the highly influential factors and the blue boxes are influenced factors. They identify a pattern for social and ecological innovation strategies based on community garden. 
Subsequently, the Student's $t$-test was conducted to evaluate the significance of the correlation analysis and relevant values. The result of this test shows that most of the variables have a cause-effect relationship $(p<0.05(5 \%))$.

\section{Discussion}

This paper shows the community gardens in light of social, economic and environmental dimensions by using an empirical survey. From this perspective, they are acting as tools to boost sustainable development. In particular, the result of the analysis (Table 3) shows that social and environmental dimensions are the most relevant community garden attributes. Therefore, community gardens can be seen as a social and ecological innovation tool. Specifically, the result of the analysis (Table 3) has identified the most significant social and environmental factors. In particular, it is seen that the sample considers the environmental attributes of the community garden to be more important than the social ones (Table 3) due to bigger average values and smaller variance. The analyses of variance (Table 4) has also highlighted that these factors are not dependent on or influenced by the different age classes used in the empirical survey. Therefore, they can be considered as universally accepted factors. Finally, the ubsequent correlation analysis (Table 5) has also identified the relationship (direction and magnitude) between the environmental and social attributes of community gardens. This result was important in identifying the high influencing factors, i.e., those factors that have a greater potential to influence other attributes. Thus, these results provide useful and insight information in order optimize social and ecological innovation strategies by creating a pattern based on the high influencing factors.

According to the result of the analysis (Table 3), the most important social variables are "socialization and historical memory for retired people", "strengthening and sense of community" and "wellness and community". On one hand, it is clear that shared memories and rights granted to civil society groups play a role in the resilience of community gardens action. On the other hand, there is a direct dependency of the latter two variables (Tables 5 and 6). According to some empirical studies, there is a positive effect of the sense of community in increasing personal wellness (e.g., life satisfaction, loneliness), both in adult and adolescent populations [70-72] (Table 4). According to Berkman et al. [73], socially oriented behaviors and a feeling of belonging to a meaningful social context (Sense of Community) increase social well-being and reinforce social participation. This result provides a confirmation of this relationship. Therefore, policy on community gardens should investigate and take advantage of this relationship because the boosting of one of these factors will indirectly increase (70\%) the other as well. An additional effect is that the "wellness and community" also influences environmental attributes such as the redevelopment of empty or abandoned areas, urbanization effects mitigation and enhancement of local products. This correlation can be explained by the link between environmentalism and health. According to Langemeyer et al. [74], the motivations of people choosing the protection of green spaces may be related to the relationship towards environmentalism but also to health. According to some scholars [75], social cohesion and increased social contacts are the means by which the natural environment supports health promotion. This correlation can also be explained by the multi-dimensionality of the concept of wellness. According to Stoewen [76], wellness encompasses several interdependent dimensions: physical, intellectual, emotional, social, spiritual, vocational, financial and environmental. Thus, the strong interdependency of "wellness and community" attributes should be explored by the institutions and policy makers that are proposing a social innovation strategy based on a community garden framework, and this attribute can be considered as a high influential factor in the frame of that strategy.

The questions related to the section of the questionnaire aimed at investigating the environmental function have been shown huge interest from farmers in this topic [77]. All environmental variables play a strong role in the community garden definition (Table 2). The most significant attribute is the redevelopment of empty or abandoned areas, the use of natural fertilizers, the urbanization effects mitigation, the enhancement of local products and, finally, the recovery of vegetable plants. The motivation behind the redevelopment of empty or abandoned areas in community gardens could be the freedom to self-organize management practices when restoring degraded places in urban 
landscapes $[14,31,50,78]$. Several studies have confirmed that community garden initiatives are driven by several factors, such as quality of the qualities of crops for consumption, health benefits, reducing environmental footprints, empowerment and strengthening of community ties and upkeep of cultural ecosystem services $[31,79,80]$. In particular, there is one attribute, urbanization effects mitigation, which strongly influences all the other environmental factors (Tables 5 and 6) with a side effect on social factors as well. Therefore, the second highest influential factor for community garden strategy is the urbanization effects mitigation.

Table 6. Student $t$-test results ${ }^{1}$.

\begin{tabular}{|c|c|c|c|c|c|c|c|}
\hline$p$ Values & $\begin{array}{l}\text { Strengthening } \\
\text { and Sense of } \\
\text { Community }\end{array}$ & $\begin{array}{l}\text { Wellness and } \\
\text { Community }\end{array}$ & $\begin{array}{c}\text { Redevelopment } \\
\text { of Empty or } \\
\text { Abandoned } \\
\text { Areas }\end{array}$ & $\begin{array}{l}\text { Urbanization } \\
\text { Effects } \\
\text { Mitigation }\end{array}$ & $\begin{array}{c}\text { Enhancement } \\
\text { of Local } \\
\text { Products }\end{array}$ & $\begin{array}{c}\text { Increased } \\
\text { Knowledge of } \\
\text { Cultivation } \\
\text { Techniques }\end{array}$ & $\begin{array}{c}\text { Use of } \\
\text { Natural } \\
\text { Fertilizers }\end{array}$ \\
\hline $\begin{array}{l}\text { Socialization and } \\
\text { historical memory for } \\
\text { retired people }\end{array}$ & 0.011 & 0.112 & 0 & 0.001 & 0.147 & 0.254 & 0.001 \\
\hline $\begin{array}{l}\text { Strengthening and } \\
\text { sense of community }\end{array}$ & & 0.072 & 0,006 & 0.185 & 0.11 & 0.051 & 0.105 \\
\hline $\begin{array}{l}\text { Wellness and } \\
\text { community }\end{array}$ & & & 0 & 0.032 & 0.414 & 0.269 & 0.019 \\
\hline $\begin{array}{c}\text { Redevelopment of } \\
\text { empty or } \\
\text { abandoned areas }\end{array}$ & & & & 0.044 & 0 & 0 & 0.134 \\
\hline $\begin{array}{c}\text { Urbanization effects } \\
\text { mitigation }\end{array}$ & & & & & 0.012 & 0.003 & 0.327 \\
\hline $\begin{array}{l}\text { Enhancement of local } \\
\text { products }\end{array}$ & & & & & & 0.336 & 0.009 \\
\hline $\begin{array}{l}\text { Increased knowledge } \\
\text { of cultivation } \\
\text { techniques }\end{array}$ & & & & & & & 0.001 \\
\hline
\end{tabular}

According to the results of the correlation analysis (Table 5) there are two variables, wellness and community and urbanization effects' mitigation, which can influence almost all the other significant environmental and social attributes. Therefore, they are the highest influential factors needed to identify the best strategy to boost the community garden as a social and ecological tool (Table 5). Thus, community gardens can be considered as a type of urban innovation called Urban Environmental Stewardship (UES), that can promote sustainability, ecosystem services, social networks, collective identity, and sense of place [81].

Therefore, this empirical analysis shows that social innovation tools, such as community gardens, will embody the social attributes as well as the ecological dimensions. This interrelationship is crucial to achieving sustainable development. For instance, the current environmental crisis has been mainly caused by having excluded the ecological dimension from the social life [82] and not including the harmonious relationship with the environment as a critical factor to achieve social well-being. Thus, the possible short-term positive effects (e.g., production of organic food [83]) and long-term positive effects (e.g., reducing pollution) of the ecological dimension on social life have turned into negative effects (e.g., less healthy food and social limitations due to pollution). Social practices can operate in synergy with or in opposition to the local environment, producing either positive and sustainable "couplings" between social practices and environmental resources or destructive and unsustainable paths [84]. According to the results of the analysis (Table 5), the significant social and environmental factors are positively correlated to each other. Anyway, this correlation can, to some extent, evolve and change. Thus, this positive cross-correlation should be boosted and incentivized as soon as possible to obtain benefits in terms of sustainable development and avoidance of negative side effects. (e.g., gardeners perceive the community as a place to be isolated from the rest of the society).

In this perspective, community gardens have the capacity to create social and ecological capital that can enhance good practices and people's positive interactions with the environment [1]. Thus, the community garden acts as an 'indicator' [46], revealing whether the ecological dimension has a detectable effect on social life. 


\section{Conclusions}

According to the result of the empirical survey, the community gardens can be seen as a strategic "social and ecological innovation tool" for achieving sustainable development within cities as well as in rural areas. They should be considered as an infrastructure with the power of renewing the city, not only in terms of image, but also from a social-environmental perspective as well. However, the result of this analysis is limited to a specific Italian area. Thus, further validation of the result is needed to substantiate the significance of community gardens attributes and the relevant highly influential factors as well as to extend the results to rural areas.

This analysis was important to show the linear dependency between variables and the existence of cause and effect correlations. This study does not provide evidence to substantiate that highly influential factors can be considered as the cause and the other variables as the effects, and so further studies, as well as a pilot, should be carried out to validate this additional hypothesis.

The future evolution of community gardens must aim at a broader social environmental perspective, such as the redevelopment of empty or abandoned areas [85]. It is hoped that the result of this paper can be used by the institutions as triggering element for boosting community gardens initiatives. These activities feed social and environmental innovation in the territories in which these practices are activated but, for the future, these practices require the continuous collaboration of all the territorial actors: local administrations, managers of community gardens and farmers. As described in the paper, community gardens can truly represent a new frontier of socio-ecological innovation and sustainable development, and this would also be a way of promoting and protecting the territory by making use of a more incisive and effective communication system [86].

Author Contributions: Conceptualization, D.S.; Founding acquisition, D.S.; Investigation, V.R.; Methodology, V.R.; Project administration, D.S.; Supervision, D.S.; Validation, G.C.; Visualization, G.C.; Writing-original draft, G.C., V.R.; Writing: review \& editing, C.G., V.R.; All authors have read and agreed to the published version of the manuscript.

Funding: This contribution has been published thanks to the local research funds of Professor Debora Scarpato (Department of Economic \& Legal Studies, University of Naples "Parthenope").

Acknowledgments: The authors thank Progetto Pace Association and Social Garden of Health and Wellness (Orto sociale della salute e del benessere) of Ponticelli for their availability.

Conflicts of Interest: The authors declare no conflict of interest.

\section{References}

1. Mensah, J.; Ricart Casadevall, S. Sustainable development: Meaning, history, principles, pillars, and implications for human action: Literature review. Cogent Soc. Sci. 2019, 5, 1653531. [CrossRef]

2. Haughton, G. Environmental justice, and the sustainable city. J. Plan. Educ. Res. 1999, 18, 233-243. [CrossRef]

3. Olsson, P.; Galaz, V. Social-ecological innovation and transformation. In Social Innovation; Palgrave Macmillan: London, UK, 2012; pp. 223-247.

4. Keeble, B.R. The Brundtland report: 'Our common future'. Med. War 1988, 4, 17-25. [CrossRef]

5. Duit, A.; Galaz, V. Governance and complexity-Emerging issues for governance theory. Governance 2008, 21, 311-335. [CrossRef]

6. Walker, B.H.; Barrett, S.; Galaz, V.; Polasky, S.; Folke, C.; Engström, G.; Ackerman, F.; Arrow, K.; Carpenter, S.R.; Chopra, K.; et al. Looming global-scale failures and missing institutions. Science 2009, 325, 1345-1346. [CrossRef]

7. Phills, J.A.; Deiglmeier, K.; Miller, D.T. Rediscovering social innovation. Stanf. Soc. Innov. Rev. 2008, 6, 34-43.

8. Cunha, J.; Benneworth, P.; Oliveira, P. Social entrepreneurship and social innovation: A conceptual distinction. In Handbook of Research on Global Competitive Advantage through Innovation and Entrepreneurship; Farinha, L.M.C., Ferreira, J.J.M., Smith, H.L., Bagchi-Sen, S., Eds.; IGI-Global: New York, NY, USA, 2011; pp. 1-24.

9. Innovation, D.S. The Young Foundation. Social Innovation Overview: A Deliverable of the Project: "The Theoretical, Empirical and Policy Foundations for Building Social Innovation in Europe" (TEPSIE), European Commission-7th Framework Programme; DG Research; European Commission: Brussels, Belgium, 2012. 
10. Geels, F.W.; Schot, J. Typology of sociotechnical transition pathways. Res. Policy 2007, 36, 399-417. [CrossRef]

11. Rotman, J.; Ye, Y.; Sorrentino, R.; Szeto, A.; Dalke, K.; Yoshida, E. The Influence of Implicit Cultural Norms versus Personal Attitudes and Uncertainty Orientation on Eating Behavior. MindPad 2011, 1. Available online: https://cpa.ca/docs/File/Students/MindPad/Mind\%20Pad_Dec\%202011.pdf (accessed on 30 May 2020).

12. Loorbach, D.; Rotmans, J. The practice of transition management: Examples and lessons from four distinct cases. Futures 2010, 42, 237-246. [CrossRef]

13. Nicholls, A.; Murdock, A. Social Innovation: Blurring Boundaries to Reconfigure Markets; Springer: Berlin, Germany, 2011.

14. Fischer, G. World food and agriculture to 2030/50. In Technical Paper from the Expert Meeting on How to Feed the World; FAO Economic and Social Development Department: Rome, Italy, 2009; Volume 2050, pp. $24-26$.

15. FAO. The State of Food and Agriculture; Food \& Agriculture Org.: Rome, Italy, 2001; No. 33.

16. Grau, H.R.; Aide, M. Globalization and land-use transitions in Latin America. Ecol. Soc. 2008, $13,16$. [CrossRef]

17. Olsson, P.; Galaz, V.; Boonstra, W.J. Sustainability transformations: A resilience perspective. Ecol. Soc. 2014, 19, 1. [CrossRef]

18. Gordon, L.J.; Finlayson, C.M.; Falkenmark, M. Managing water in agriculture for food production and other ecosystem services. Agric. Water Manag. 2010, 97, 512-519. [CrossRef]

19. West, J.; Salter, A.; Vanhaverbeke, W.; Chesbrough, H. Open Innovation: The Next Decade; Elsevier: Shannon, Ireland, 2014.

20. Guerrero Lara, L.; Pereira, L.M.; Ravera, F.; Jiménez-Aceituno, A. Flipping the Tortilla: Social-ecological innovations and traditional ecological knowledge for more sustainable agri-food systems in Spain. Sustainability 2019, 11, 1222. [CrossRef]

21. Pereira, L.; Karpouzoglou, T.; Doshi, S.; Frantzeskaki, N. Organising a safe space for navigating social-ecological transformations to sustainability. Int. J. Environ. Res. Public Health 2015, 12, 6027-6044. [CrossRef] [PubMed]

22. Lang, U. The common life of yards. Urban Geogr. 2014, 35, 852-869. [CrossRef]

23. Simon-Rojo, M.; Recasens, X.; Callau, S.; Duzi, B.; Eiter, S.; Hernández-Jiménez, V.; Vejre, H. Chapter 1.2: From urban food gardening to urban farming. In Urban Agriculture Europe; Jovis: Berlin, Germany, 2015; pp. 22-28.

24. Groening, G.; Hennecke, S. Urban greening-Macro Scale Landscaping. In A Cura di Horticulture: Plants for People and Place; Dixon, G., Aldous, D., Eds.; Spinger: London, UK, 2014; pp. 671-692.

25. Guitart, D.; Pickering, C.; Byrne, J. Past results and future directions in urban community gardens research. Urban For. Urban Green. 2012, 11, 364-373. [CrossRef]

26. Shur-Ofry, M.; Malcai, O. Collective action and social contagion: Community gardens as a case study. Regul. Gov. 2019. [CrossRef]

27. Konijnendijk, C.; Gauthier, M. Urban forestry for multifunctional urban land use. Cities farming for the future. In Urban Agriculture for Sustainable Cities; RUAF Foundation, IDRC and IIRR: Copenhagen, Denmark, 2006; pp. 411-442.

28. Huang, S.; Harris, K.D.; Lopez-Capel, E.; Manning, D.A.; Rickard, D. "Amorphous nickel sulfide" is hydrated nanocrystalline NiS with a core- Shell structure. Inorg. Chem. 2009, 48, 11486-11488. [CrossRef]

29. Tsilini, V.; Papantoniou, S.; Kolokotsa, D.D.; Maria, E.A. Urban gardens as a solution to energy poverty and urban heat island. Sustain. Cities Soc. 2015, 14, 323-333. [CrossRef]

30. Alaimo, K.; Packnett, E.; Miles, R.A.; Kruger, D.J. Fruit and vegetable intake among urban community gardeners. J. Nutr. Educ. Behav. 2008, 40, 94-101. [CrossRef]

31. Sanecka, J.; Barthel, S.; Colding, J. Countryside within the city: A motivating vision behind civic green area stewardship in Warsaw, Poland. Sustainability 2020, 12, 2313. [CrossRef]

32. Barthel, S.; Folke, C.; Colding, J. Social-ecological memory in urban gardens-Retaining the capacity for management of ecosystem services. Glob. Environ. Chang. 2010, 20, 255-265. [CrossRef]

33. Filkobski, I.; Rofè, Y.; Tal, A. Community gardens in Israel: Characteristics and perceived functions. Urban For. Urban Green. 2016, 17, 148-157. [CrossRef]

34. Bradley, K.; Galt, R.E. Practicing food justice at Dig Deep Farms \& Produce. East Bay. Local Environ. $2013,19$. [CrossRef] 
35. Slow Food. Available online: https://www.slowfood.it/orto-urbano-un-bene-la-terra-un-alleato-gli-sprechi/ (accessed on 30 May 2020).

36. Grahn, P.; Ivarsson, C.T.; Stigsdotter, U.K.; Bengtsson, I.L. Using Affordances as a Health-Promoting Tool in a Therapeutic Garden. In Innovative Approaches to Researching Landscape and Health; Thompson, C.W., Bell, S., Aspinall, P., Eds.; Routledge: London, UK, 2010; pp. 116-154.

37. Demers, M. Cultivating Well-being: Horticulture Programming's Effect on Youth's Emotional Well-Being. Master's Thesis, St. Catharine University, Saint Paul, MN, USA, 2013.

38. Kingsley, J.Y.; Townsend, M.; Henderson-Wilson, C. Cultivating Health and Wellbeing: Members' Perceptions of the Health Benefits of a Port Melbourne Community Garden. Leis. Stud. 2009, 28, 207-219. [CrossRef]

39. Heliker, D.; Chadwick, A.; O'Connell, T. The meaning of gardening and the effects on perceived well-being of a gardening project on diverse populations of elders. Act. Adapt. Aging 2001, 24, 35-56. [CrossRef]

40. Cognetti, F. Milano, coltivazione urbana e percorsi di vita in comune. Note da una ricerca in corso. Milan Urban Cultiv. Common Lifepaths 2012, 60, 33-38. [CrossRef]

41. Butler, D.; Parkinson, J. Towards Sustainable Urban Drainage. Water Sci. Technol. 1997, 35, 53-63. [CrossRef]

42. Gasperi, D.; Pennisi, G.; Rizzati, N.; Magrefi, F.; Bazzocchi, G.; Mezzacapo, U.; Gianquinto, G. Towards regenerated and productive vacant areas through urban horticulture: Lessons from Bologna, Italy. Sustainability 2016, 8, 1347. [CrossRef]

43. Ferris, J.; Norman, C.; Sempik, J. People, land, and sustainability: Community gardens and the social dimension of sustainable development. Soc. Policy Admin. 2001, 35, 559-568. [CrossRef]

44. Cattivelli, V. Not Just Food: The (New) Importance of Urban Gardens in the Modern Socio-economic System. A Brief Analysis. In World Food Trends and the Future of Food; Ledizioni: Milano, Italy, 2015; pp. 55-74.

45. Moisander, J.; Pesonen, S. Narratives of sustainable ways of living: Constructing the self and the other as a green consumer. Manag. Decis. 2002, 40, 329-342. [CrossRef]

46. Sepúlveda, S.; Edwards, R. Sustainable Development: Social Organization, Institutional Arrangements and Rural Development: Selected Readings; Inter-American Institute for Cooperation on Agriculture: San Isidro, Argentina, 1997.

47. Camps-Calvet, M.; Langemeyer, J.; Calvet-Mir, L.; Gómez-Baggethun, E.; March, H. Sowing resilience and contestation in times of crises: The case of urban gardening movements in Barcelona. Partecip. Conflitto 2015, $8,417-442$.

48. Rusciano, V.; Civero, G.; Scarpato, D. Urban gardens in the city of Naples: An empirical analysis. Calitatea 2018, 19, 436-442.

49. Rusciano, V.; Civero, G.; Scarpato, D. Urban gardening as a new frontier of wellness: Case studies from the city of Naples. Int. J. Sustain. Econ. Soc. Cult. Context 2017, 13, 39-49. [CrossRef]

50. Krasny, M.E.; Tidball, K.G. Civic Ecology: Adaptation and Transformation from the Ground Up; MIT Press: Cambridge, MA, USA, 2015.

51. Barthel, S.; Isendahl, C. Urban gardens, agriculture, and water management: Sources of resilience for long-term food security in cities. Ecol. Econ. 2013, 86, 224-234. [CrossRef]

52. Dennis, M.; James, P. Considerations in the valuation of urban green space: Accounting for user participation. Ecosyst. Serv. 2016, 21, 120-129. [CrossRef]

53. Svendsen, E.; Campbell, L.K. Urban ecological stewardship: Understanding the structure, function and network of community-based urban land management. Cities Environ. CATE 2008, 1, 4.

54. Westphal, C.; Steffan-Dewenter, I.; Tscharntke, T. Mass flowering crops enhance pollinator densities at a landscape scale. Ecol. Lett. 2003, 6, 961-965. [CrossRef]

55. Dennis, M.; James, P. Evaluating the relative influence on population health of domestic gardens and green space along a rural-urban gradient. Landsc. Urban Plan. 2017, 157, 343-351. [CrossRef]

56. Hynes, H.P.; Howe, G. Urban horticulture in the contemporary United States: Personal and community benefits. Int. Conf. Urban Horticult. 2002, 643, 171-181. [CrossRef]

57. Cameron, R.W.; Blanuša, T.; Taylor, J.E.; Salisbury, A.; Halstead, A.J.; Henricot, B.; Thompson, K. The domestic garden-Its contribution to urban green infrastructure. Urban For. Urban Green. 2012, 11, 129-137. [CrossRef]

58. Curtin, S.; Fox, D. Human dimension of Wildlife Gardening: Its development, controversies, and psychological benefits. In A Cura di Horticulture: Plants for People and Place; Dixon, G., Aldous, D., Eds.; Spinger: London, UK, 2014; pp. 1025-1046. 
59. Doxon, L.E.; Mattson, R.H.; Jurich, A.P. Human stress reduction through horticultural vocational training. HortScience 1987, 22, 655-656.

60. Evers, A. Food choices and local food access among Perth's community gardeners. Local Environ. 2011, 16, 585-602. [CrossRef]

61. Irvine, S.; Johnson, L.; Peters, K. Community gardens and sustainable land use planning: A case-study of the Alex Wilson Community Garden. Local Environ. 1999, 4, 33-46. [CrossRef]

62. Bower, K.M. Analysis of Variance (ANOVA) using MINITAB. Sci. Comput. Instrum. 2000, 17, $64-65$.

63. Von Eye, A.; Bogat, G.A. Methods of data analysis in person-oriented research-The sample case of ANOVA. In Jahrbuch Jugendforschung; VS Verlag für Sozialwissenschaften: Berlin, Germany, 2006; pp. 161-182.

64. Hogg, R.V.; Ledolter, J. Applied Statistics for Engineers and Physical Scientists; Macmillan Publishing Company: New York, NY, USA, 1987.

65. Franzese, M.; Iuliano, A. Correlation Analysis; Elsevier: Aalborg, Denmark, 2019; pp. 706-721.

66. Obilor, E.I.; Amadi, E.C. Test for Significance of Pearson's Correlation Coefficient; SEAHI Publications: Harjumaa, Estonia, 2018.

67. Aldrich, J. Correlations genuine and spurious in Pearson and Yule. Stat. Sci. 1995, 10, 364-376. [CrossRef]

68. Student. The probable error of a mean. Biometrika 1908, 6, 1-25. [CrossRef]

69. Fisher, R.A. Statistical Methods for Research Workers; Oliver \& Boyd: Edinburgh, UK, 1925.

70. Pretty, G.M.; Conroy, C.; Dugay, J.; Fowler, K.; Williams, D. Sense of community and its relevance to adolescents of all ages. J. Commun. Psychol. 1996, 24, 365-379. [CrossRef]

71. Prezza, M.; Amici, M.; Roberti, T.; Tedeschi, G. Sense of community referred to the whole town: Its relations with neighboring, loneliness, life satisfaction, and area of residence. J. Commun. Psychol. 2001, 29, 29-52. [CrossRef]

72. Chipuer, H.M. Youths' discourses on their school environment: How schools are meeting youths' needs. Educ. Weav. Res. Pract. 2004, 1, 206.

73. Berkman, L.F.; Glass, T. Social integration, social networks, social support, and health. Soc. Epidemiol. 2000, 1, 137-173.

74. Langemeyer, J.; Camps-Calvet, M.; Calvet-Mir, L.; Barthel, S.; Gómez-Baggethun, E. Stewardship of urban ecosystem services: Understanding the value (s) of urban gardens in Barcelona. Landsc. Urban Plan. 2018, 170, 79-89. [CrossRef]

75. Hartig, T.; Mitchell, R.; De Vries, S.; Frumkin, H. Nature and health. Annu. Rev. Public Health 2014, 35, 207-228. [CrossRef] [PubMed]

76. Stoewen, D.L. Dimensions of wellness: Change your habits, change your life. Can. Vet. J. 2017, 58, 861. [PubMed]

77. Williamson, S. Challenges for farmer participation in integrated and organic production of agricultural tree crops. Biocontrol News Inf. 2002, 23, 25-36.

78. Kent, F. Open Letter: This is What Democracy Looks Like. Available online: https://www.pps.org/blog/ openletter-democracy-looks-like/ (accessed on 15 November 2018).

79. Opitz, I.; Berges, R.; Piorr, A.; Krikser, T. Contributing to food security in urban areas: Differences between urban agriculture and peri-urban agriculture in the Global North. Agric. Hum. Values 2016, 33, 341-358. [CrossRef]

80. Pourias, J.; Čakovská, B.; March, H.; Nordh, H.; Calvet-Mir, L. How to Take into. Account Gardeners' Motivations into Urban Garden Planning? Urban Gardens in Europe Challenge. Available online: http://www.urbanallotments.eu/fact-sheets.html (accessed on 5 May 2019).

81. Connolly, J.J.; Svendsen, E.S.; Fisher, D.R.; Campbell, L.K. Networked governance and the management of ecosystem services: The case of urban environmental stewardship in New York City. Ecosyst. Serv. 2014, 10, 187-194. [CrossRef]

82. Gieryn, T.F. A space for place in sociology. Annu. Rev. Sociol. 2000, 26, 463-496. [CrossRef]

83. Civero, G.; Rusciano, V.; Scarpato, D. Orientation of Agri-Food Companies to CSR and Consumer Perception: A Survey on Two Italian Companies. Recent Patents Food Nutr. Agric. 2018, 9, 134-141. [CrossRef]

84. Baker, S.; Mehmood, A. Social innovation and the governance of sustainable places. Local Environ. 2015, 20, 321-334. [CrossRef] 
85. Bartoletti, R.; Paltrinieri, R. Consumo e prosumerismo in rete: Processi di creazione di valore. Sociol. Della Comun. 2012, 43, 7-14.

86. Rusciano, V.; Civero, G.; Scarpato, D. Urban gardens and environmental sustainability: An empirical research of Campania region. Calitatea 2017, 18, 376-381. 